\title{
Awareness Scale for Reducing Ecological Footprint: A Validity and Reliability Study
}

\author{
Mustafa Agah Tekindal ${ }^{1 *}$, Gözde Zabzun², Zeynep Özel ${ }^{3}$, Mert Demirsöz ${ }^{4}$, Melike Tekindal ${ }^{5}$ \\ 1* İzmir Katip Çelebi University, Faculty of Medicine, Departmant of Biostatistics, İzmir, Turkey, (ORCID: 0000-0002-4060-7048), matekindal@gmail.com \\ ${ }^{2}$ Ege University, Institute of Education Sciences, Departmant of Department of Computer Education and Instructional Technologies, İzmir, Turkey, (ORCID: 0000- \\ 0002-9502-8756), gzabzun@gmail.com \\ ${ }^{3}$ Selçuk University, Faculty of Veterinary Medicine, Departmant of Biostatistics, Konya, Turkey, (ORCID: 0000-0002-1077-1250), zozel4225@gmail.com \\ ${ }^{4}$ KTO Karatay University, Technology Transfer Office, Konya, Turkey, (ORCID: 0000-0002-4800-2529), mertdmrsz17@gmail.com \\ 5 İzmir Katip Çelebi University, Faculty of Health Sciences, Departmant of Social Work, İzmir, Turkey, (ORCID: 0000-0002-3453-3273), \\ meliketunctekindal@gmail.com
}

(First received 28 May 2021 and in final form 23 September 2021)

(DOI: $10.31590 /$ ejosat.944221)

ATIF/REFERENCE: Tekindal, M. A., Zabzun, G., Özel, Z., Demirsöz, M. \& Tekindal, M. (2021). Awareness Scale for Reducing Ecological Footprint: A Validity and Reliability Study. European Journal of Science and Technology, (27), 439-445.

\begin{abstract}
People form a whole by interacting with the environment in which they live. With this interaction, the use of natural resources takes place. This study was carried out in a methodological manner in order to develop a measurement tool that will raise awareness for the reduction of damage by focusing on the concept of environmental responsibility with increasing ecological problems. The research was applied to 203 people and a pilot study was conducted. Validity and reliability analyzes were made with the results obtained from this questionnaire. After this, the study was completed by applying the scale, whose validity and reliability was finally provided to 260 individuals. The questionnaires were applied between 16 and January 27, 2021, with the approval. In the study, after the factors were determined by explanatory factor analysis as a result of the pilot study applied to 203 people, they were tested with confirmatory factor analysis to test the suitability of the factor structures. The model obtained according to the fit index values was found to fit well. According to the findings obtained from the study, it was determined that the scale is a measurement tool with high validity and reliability. It is recommended to be used in determining ecological footprint awareness.
\end{abstract}

Keywords: Ecological footprint, Environment, Validity and reliability

\section{Ekolojik Ayak İzinin Azaltılmasına Yönelik Farkındalık Ölçeği Geçerlik ve Güvenirlik Çalışması}

$\ddot{O} z$

İnsanlar yaşadıkları çevre ile etkileşim kurarak bir bütün oluşturur. Bu etkileşim ile doğal kaynakların kullanımı gerçekleşir. Bu çalışma, artan ekolojik problemler ile birlikte çevresel sorumluluk kavramına odaklanarak verilen zararın azaltılmasına yönelik farkındalık oluşturacak bir ölçme aracı geliştirmek amacıyla metodolojik türde yapılmıştır. Araştırma, 203 kişiye uygulanarak pilot çalışma yapılmıştır. Bu anketten elde edilen sonuçlar ile geçerlilik güvenilirlik analizleri uygulanmıştır. Daha sonrasında 260 kişiye geçerliği ve güvenilirliği sağlanan ölçek uygulanarak çalışma sonlandırılmıştır. Anketler onay alınarak, 16 Ocak - 27 Ocak 2021 tarihleri arasında uygulanmıştır. Çalışmada 203 kişiye uygulanan pilot çalışma sonucunda faktörler açıklayıcı faktör analizi (AFA) ile belirlendikten sonra, faktör yapılarının uygunluğunu test etmek için doğrulayıcı faktör analizi (DFA) ile test edildi. Uyum indeksi değerlerine göre elde edilen model iyi uyum sağladığı görüldü. Çalışma sonucu elde edilen bulgulara göre Ölçeğinin yüksek geçerlik ve güvenirliğe sahip olan bir ölçüm aracı olmasından dolayı ekolojik ayak izi farkındalığı belirlenmesinde kullanılması önerilmektedir.

Anahtar Kelimeler: Ekololojik ayak izi, Çevre, Geçerlilik güvenilirlik

* Corresponding Author: matekindal@gmail.com 


\section{Introduction}

People interact with the environment for their vital needs. Scarce natural resources are used for vital activities. With the industrialization and population growth, environmental problems grow rapidly and become a problem that erodes natural resources and threatens the planet (Tosunoğlu, 2014).

Ecological destruction occurs as a result of the deterioration of the ecosystem balance caused by the environmental problems and it expands by threatening the world, i.e. the habitat of living things. Factors such as industrialization, technological development, rapid consumption of natural resources cause an increase in ecological destruction and become a world problem (Akıll1, Kemahl1, Okudan, 2008).

With the rapid increase of environmental problems and observation of their consequences, new concepts have emerged to raise awareness of these problems. "Ecological Footprint" is one of these concepts. This concept was first introduced by Prof. William Rees, Dr. Mathis Wackernagel, et al. The purpose of the concept is to find out which factors the damage is caused by using a new calculation method for measuring the productivity and amount of natural resources, consuming natural resources and developing solutions to prevent damage to these concepts (Ak1ll, et al., 2008: 7; Ruževičius, 2010).

Ecological Footprint is a calculation [measurment] technique that shows the amount of natural resources consumed in the world, the size of the areas required for waste disposal, and how biologically productive areas are used by countries or individuals (Rapport, 2000).

With this technique, the water and fertile land area required for the production of the consumed resources and the control of the waste generated in this process can be expressed in terms of "global hectares" $(g h a)$. The main purpose is to calculate how long this ecological destruction will last by constantly consuming natural resources by living creatures and creating the waste as a result. Based on this calculation, it will be able to reveal the amount of remaining natural resources and generate the solutions that can prevent the ecological destruction (Tosunoğlu, 2014; Costanza, 2000).

In this respect, the national scale calculation formula for the ecological footprint is expressed as follows (Kaypak, 2013):

Ecological Footprint $(h a)=$ Consumption $\times$ Production Area $\times$ Population

The consumption variable in the ecological footprint formula is expressed as the proxy for the use of resources. Production area represents the amount of biological production area that can be met in the amount consumed (Lenzen, Hansson, Bond, 2007).

For the continuity of life, the ecological footprint is an effective tool in raising the awareness of people's environmental behaviors, as it expresses the destruction caused by living creatures on the planet in numerical [quantitative] terms (Keleş, Naim, Özsoy, 2008; Coşkun and Sarıkaya, 2014).

The main purpose of this study is, in view of increasing ecological problems, to develop a measurement tool that will raise awareness about reducing the damage to natural resources and environment by focusing on the concept of environmental responsibility for global life of individuals and countries. With this tool, more efficient use of the resources can draw attention to the environmental damage and guide for a more sustainable life.

The main motivation of the study is to determine the ecological footprint awareness of the parents of the students and to create awareness in their children.

\section{Material and Method}

In this study, it was aimed to develop a new scale on ecological footprint by applying the validity and reliability analyzes of the scale. In the research, scanning model technique, which is one of the quantitative research methods, was used. This model consists of arrangements made by taking a group of samples to make a general assessment about the universe (Karasar, 2020). This study was planned and evaluated as crosssectional.

\subsection{Research Design}

This study was conducted to determine the awareness levels for the parents of students to reduce the ecological footprint. The research was applied to 203 individuals in Çiğli district center of İzmir province and a pilot study was conducted. Validity and reliability analyzes were made with the results obtained from this questionnaire [survey]. After this, the study was completed by applying the scale, whose validity and reliability was finally provided to 260 individuals. The questionnaires were applied between January 16, 2021 and January 27, 2021, with the approval of the parents. The questionnaire form used in the study is given in Annex 1.

\subsection{Sample Size}

The sample size to be used for the validity study was determined as at least 195 people, with the help of the GPOWER program, the required number of observations for the Cronbach Alpha $(\alpha)$ method. Accordingly, the power of the test was expected to be about $80 \%$. When the power analysis of the study was made, it was determined that there were at least 195 people at $5 \%$ error level and $85 \%$ power level.

\subsection{Sample Size}

The study the Awareness Scale for Reducing the Ecological Footprint consists of six sub-dimensions: Energy, Under the Laws, Recycling, Transportation, Water Consumption and Food. Energy sub-dimension 1., 2., 3., 4., 5., 6., 7., 8. Under Laws, 9., 10., 11., 12., Recycling 13., 14., 15., 16., 17., Transportation 18., 19., 20., 21., 22., Food 23., 24., 25., 26., Water Consumption 27., 28., 29., 30. It consists of questions. Scale categories; It is obtained by summing the subscales by scoring Strongly Disagree $=1$, Disagree $=2$, Undecided $=3$, Agree $=4$ and Strongly Agree $=5$. 


\subsection{Statistical Methods}

The data [in this study] were analyzed using IBM SPSS Statistics for Windows (Version 25.0) and Amos (Version 24.0) statistical package program.

The following tests were performed to evaluate the validity of the scale: Cronbach alpha coefficient for internal consistency between items, Tukey summability test for summability, KaiserMeyer-Olkin (KMO) test for the adequacy of the number of units in the sample, Barlett test for factorizability, Principal Component Analysis (PCA) for determining the factors structure. Scale reliability was analyzed by the test-retest, intragroup correlation coefficients, parametric and non-parametric methods in paired samples. Finally, an appropriate Structural Equation Model (SEM) for the confirmatory factor analysis was created and the accuracy of this model was checked with the fit index values, and the relationships between the concepts of the scale were determined (Demirsöz, Özel, Yonar, Tekin, Tekindal, 2021).

\subsection{Ethical Responsibility}

In the study, the permission was received from the ethics committee and the relevant institution. In addition, the purpose of the study was explained to the participants and their approval was obtained. The study was approved by the Local Ethics İzmir Kâtip Çelebi University Social Research (Approval number: 2021/0405 Date: 08/04/2021).

\subsection{Awareness Scale For Reducing The Ecological Footprint}

The purpose of constructing the Ecological Footprint Scale is to plan the natural resources that are consumed and needed individually or socially. [In this study] Items were scored using the 5-point Likert scale as follows: 1: Strongly Disagree, 2: Disagree, 3: Undecided (Neutral), 4: Agree, 5: Strongly Agree.

\section{Results and Discussion}

Table 1. Common Factor Variances and Factor Loadings for Awareness Scale for Reducing the Ecological Footprint

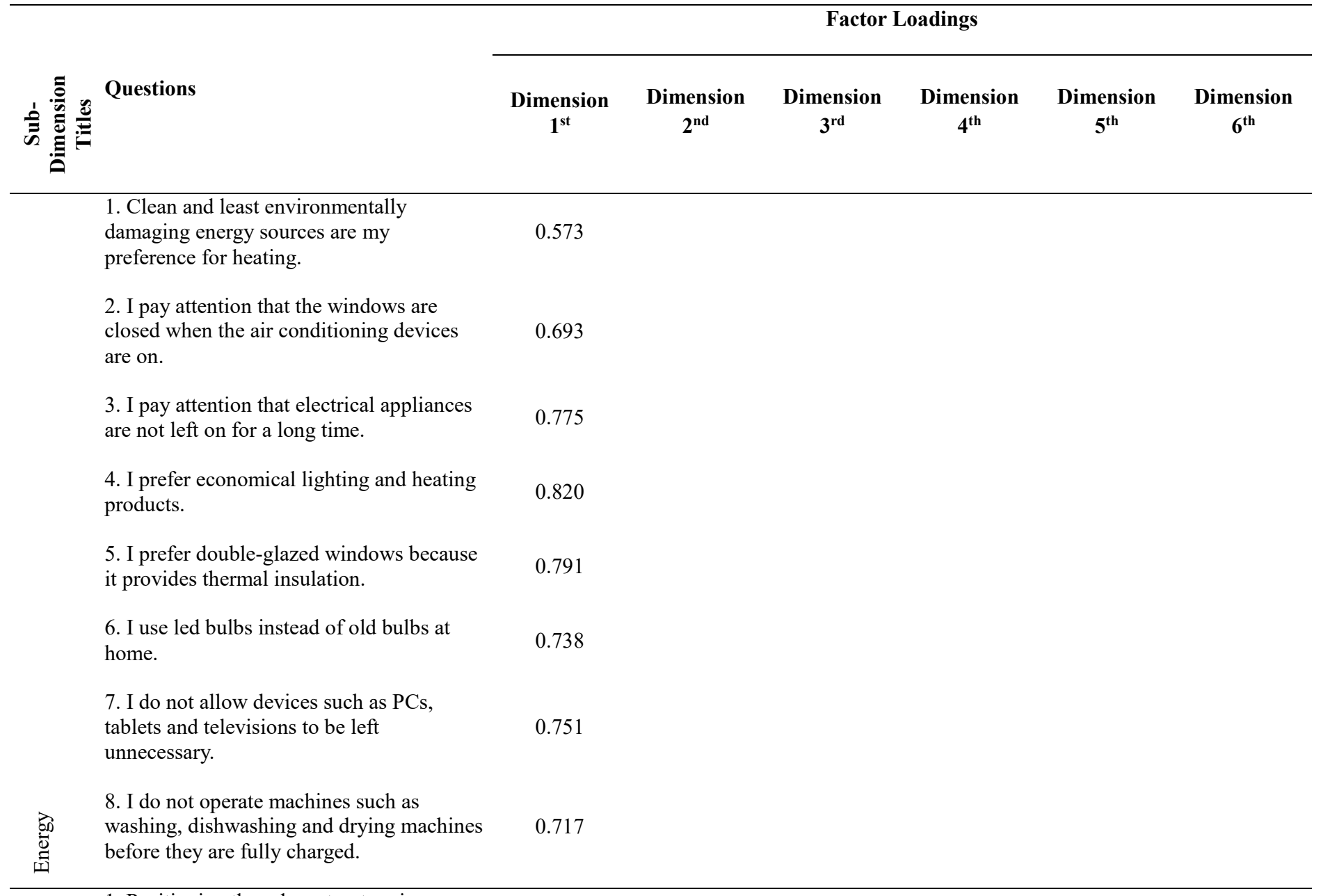

\footnotetext{
1. Positioning the urban structure in a way that solar energy can be used effectively is beneficial for the environment.

2. I think that the sale of vehicles with the least impact on the deterioration of the ecological balance should be encouraged by the government.
} 
3. I think that green areas should not be abandoned for urbanization and industrialization.

4. I think that the measures to protect environmental health and prevent pollution of natural resources for industrial entities should be within the scope of legal obligation.

3. I try to use leftovers in a different way instead of throwing away.

4. I sort the wastes in the house according to their structure and throw them away.

1. I prefer to share the same car with others as it is less harmful to the environment.

2. I prefer to use public transport because it is less harmful to the environment.

3. I prefer vehicles such as ginger, scooters and electric skateboards as they are less harmful to the environment.

4. I prefer cycling to driving.

5. If the distance is appropriate, I prefer walking to driving.

1. I prefer wiping instead of washing to ensure less water consumption in car cleaning.

2. I prefer cosmetic products that do not harm the environment in the content of cleaning materials.

3. I take care not to waste more water than necessary for personal cleaning.

4. I prefer to water the plants in the house/garden using appropriate methods.

1. I do not eat foods that are not in season.

2. When shopping for food, I buy it as much as I need.

\begin{tabular}{ccccccc}
\hline Core Values & 6.001 & 3.818 & 3.609 & 2.866 & 2.844 & 2.813 \\
\hline Variance Description Ratios \% & 20.002 & 12.727 & 12.029 & 9.554 & 9.479 \\
\hline Croncbachs'Alpha $(\alpha)$ & 0.940 & 0.920 & 0.909 & 0.819 & 0.886 & 0.814 \\
\hline
\end{tabular}


Total Variance Ratio $=73.169$

Kaiser-Meyer-Olkin $(\mathrm{KMO})=0.934$

Bartlett test value $=5085.799 \mathbf{p}=\mathbf{0 . 0 0 1} * *$

Croncbachs'Alpha $(\alpha)=0.960$

$\mathrm{p}^{*}<0.05 \quad \mathrm{p}^{* *}<0.01$

The KMO test is used to test whether the distribution is suitable for the factor analysis and a value above 0.90 is considered perfect. Based on this information, it can be said that the $\mathrm{KMO}$ value in this study was at a very good level. Barlett test result was obtained as $5085.799(p<0.05)$. According to this result, it was revealed that the applied measurement variable was multivariate in the universe parameter. In this study, the factors with eigenvalues greater than 1.50 and the factors with no limitations on the number of factors were included in the scale. Factors with an eigenvalue of 1 or greater are considered as the important factors in the factor analysis.

Considering that the variance rates varying between $60 \%$ and $80 \%$ in the factor analysis are considered ideal, it can be said that the amount of variance obtained in this study is at an appropriate level (Fornell and Lacker, 1981; Peterson, 2000).

According to the table; the factor loads of the questions in the first dimension (Energy) are between 0.573 and 0.820 , the factor loads of the questions in the second dimension (Legal Scope (Laws Factor)) are between 0.761 and 0.824 , the factor loads of the questions in the third dimension (Recycling) are between 0.600 and 0.801 , the factor loads of the questions in the fourth dimension (Transportation) vary between 0.461 and 0.798 , the factor loads of the questions in the fifth dimension (Water Consumption) are between 0.615 and 0.763 , and the factor loads of the questions in the sixth dimension (Nutrition (Food)) vary between 0.546 and 0.768 .

Since Croncbachs' Alpha $(\alpha)$ was above 0.70 , its reliability was deemed sufficient (Cronbach, 1951). For this reason, subfeatures of 6 dimensions of the Awareness Scale for Reducing
Ecological Footprint were measured. The questionnaire created according to these results is a reliable measurement tool.

The model obtained for the Awareness Scale for Reducing the Ecological Footprint $\left(\chi^{2}=988.077, \mathrm{df}=381\right)$ consists of six dimensions [sub-scales]. The fit indices for this model showed that the model was fitted at an acceptable level (Table 2).

Table 2. Statistical Values Regarding the Fit of the Structural

Equation Model (Erkorkmaz, Etikan, Demir, Özdamar, Sanisoğlu 2013)

\begin{tabular}{|c|c|c|c|}
\hline Measurement & $\begin{array}{c}\text { Good } \\
\text { Fit }\end{array}$ & $\begin{array}{c}\text { Acceptable } \\
\text { Fit }\end{array}$ & $\begin{array}{c}\text { Fit Index Values } \\
\text { of the Model }\end{array}$ \\
\hline$\left(X^{2} / \mathrm{sd}\right)$ & $\leq 3$ & $\leq 4-5$ & $2.600 * *$ \\
\hline RMSEA & $\leq 0.05$ & $0.06-0.08$ & $0.079 *$ \\
\hline IFI & $\geq 0.95$ & $0.94-0.90$ & $0.921 * *$ \\
\hline CFI & $\geq 0.97$ & $\geq 0.95$ & $0.921 * *$ \\
\hline GFI & $\geq 0.90$ & $0.89-0.85$ & $0.803 * *$ \\
\hline TLI & $\geq 0.95$ & 0.94-0.90 & $0.910 * *$ \\
\hline
\end{tabular}

When the fit indices were examined according to Table 2, it was understood that the model had perfect fit values. The most reliable was RMSEA. The tested model is shown in Figure 1.

Figure 1: SEM Model for Interaction Among Six Sub-Scales of Awareness Scale for Reducing Ecological Footprint

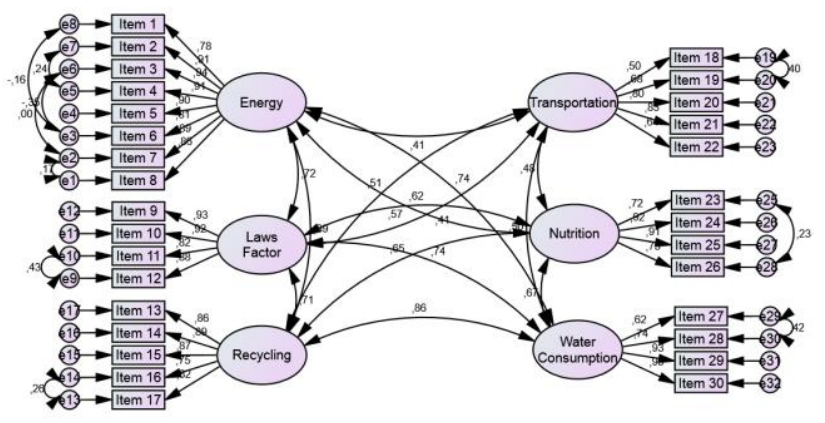


The relationships that were revealed as a result of the analysis made after the improvements [adjustments] were obtained are given in Table 3. A statistically significant positive correlation

Table 3. Structural Equation Model Regression Weights After Adjustments Made According to Modification Indexes was found between the sub-dimensions of the Awareness Scale for Reducing the Ecological Footprint $(p<0.05)$.

\begin{tabular}{|c|c|c|c|c|c|c|c|}
\hline \multicolumn{3}{|c|}{ Tested Path } & \multirow{2}{*}{$\begin{array}{c}\begin{array}{c}\text { Standardized } \\
\text { Estimation }(\beta)\end{array} \\
0.717\end{array}$} & \multirow{2}{*}{$\frac{\text { Estimation }(\beta)}{0.58}$} & \multirow{2}{*}{$\begin{array}{c}\begin{array}{c}\text { Standard } \\
\text { Error }\end{array} \\
0.07\end{array}$} & \multirow{2}{*}{$\begin{array}{c}\begin{array}{c}\text { Critical } \\
\text { Value }\end{array} \\
8.333\end{array}$} & \multirow{2}{*}{$\frac{\mathbf{p}}{0.001^{* *}}$} \\
\hline Energy & $<-->$ & $\begin{array}{r}\text { Legal Scope } \\
\text { (Laws Factor) }\end{array}$ & & & & & \\
\hline Energy & $<-->$ & Recycling & 0.686 & 0.587 & 0.074 & 7.912 & $0.001 * *$ \\
\hline Energy & $<-->$ & Transportation & 0.415 & 0.239 & 0.051 & 4.688 & $0.001^{* *}$ \\
\hline Energy & $<-->$ & $\begin{array}{c}\text { Water } \\
\text { Consumption }\end{array}$ & 0.575 & 0.439 & 0.065 & 6.770 & $0.001 * *$ \\
\hline Energy & $<-->$ & Nutrition (Food) & 0.738 & 0.515 & 0.072 & 7.206 & $0.001 * *$ \\
\hline $\begin{array}{c}\text { Legal Scope (Laws } \\
\text { Factor) } \\
\end{array}$ & $<-->$ & Recycling & 0.708 & 0.596 & 0.074 & 8.066 & $0.001 * *$ \\
\hline $\begin{array}{c}\text { Legal Scope (Laws } \\
\text { Factor) }\end{array}$ & $<-->$ & Transportation & 0.407 & 0.231 & 0.05 & 4.605 & $0.001 * *$ \\
\hline $\begin{array}{c}\text { Legal Scope (Laws } \\
\text { Factor) }\end{array}$ & $<-->$ & $\begin{array}{c}\text { Water } \\
\text { Consumption }\end{array}$ & 0.625 & 0.47 & 0.066 & 7.094 & $0.001 * *$ \\
\hline $\begin{array}{c}\text { Legal Scope (Laws } \\
\text { Factor) }\end{array}$ & $<-->$ & Nutrition (Food) & 0.742 & 0.51 & 0.07 & 7.235 & $0.001 * *$ \\
\hline Recycling & $<-->$ & Transportation & 0.513 & 0.308 & 0.059 & 5.177 & $0.001 * *$ \\
\hline Recycling & $<-->$ & $\begin{array}{c}\text { Water } \\
\text { Consumption }\end{array}$ & 0.65 & 0.517 & 0.073 & 7.096 & $0.001 * *$ \\
\hline Recycling & $<-->$ & Nutrition (Food) & 0.861 & 0.625 & 0.084 & 7.486 & $0.001 * *$ \\
\hline Transportation & $<-->$ & $\begin{array}{c}\text { Water } \\
\text { Consumption }\end{array}$ & 0.484 & 0.26 & 0.053 & 4.907 & $0.001 * *$ \\
\hline Transportation & $<-->$ & Nutrition (Food) & 0.499 & 0.244 & 0.051 & 4.840 & $0.001 * *$ \\
\hline $\begin{array}{c}\text { Water } \\
\text { Consumption }\end{array}$ & $<-->$ & Nutrition (Food) & 0.674 & 0.438 & 0.067 & 6.510 & $0.001 * *$ \\
\hline
\end{tabular}

According to Table 3, statistically significant positive relationships were found between the sub-dimensions [subscales] of the Awareness Scale for Reducing the Ecological Footprint $(p<0.05)$. The highest relationship was between the Recycling subscale and the Nutrition (Food) subscale, while the lowest relation was between the Legal Scope (Laws Factor) subscale and the Transportation subscale.

When these results are examined in general, the results of the study conducted for the Awareness Scale for Reducing the Ecological Footprint is a reliable and valid measurement tool.

In our age where the environmental problems are soaring, individuals who have the environmental awareness should transfer it to other people in order to minimize these problems. In order to raise individuals with this awareness, the ducation [fort his purpose] should be provided at school and within the family. In order to acquire the environmental awareness at school and in family, teachers and parents should have this awareness, respectively. The purpose of applying this study to parents in particular was to raise their awareness.

In addition, environmental problems bring along social problems. Peace and security between states are under threat due to resource shortages that occur with environmental problems (Canter and Ndegwa, 2002; Dalby, 2008; Güler, 2009). In order to minimize this danger [threat], social ecological footprint awareness should be constructed around the world.

The Awareness Scale for Reducing the Ecological Footprint in this study, whose validity and reliability tests have been made, 
of the scale, it can be said that it is highly reliable with a Cronbach alpha value of 0.960 .

\section{Conclusions and Recommendations}

According to the findings obtained as a result of the study, it was determined that the internal consistency coefficient of the items was highly reliable. It was also found that the scale had the construct validity. Therefore, it is recommended to use the Awareness Scale for Reducing the Ecological Footprint, as it is a measurement tool with high validity and reliability.

\section{References}

Akıllı, H., Kemahlı, F., Okudan, K., \& Polat, F. (2008). Ekolojik Ayak İzinin Kavramsal İçeriği Ve Akdeniz Üniversitesi İktisadi Ve İdari Bilimler Fakültesi'nde Bireysel Ekolojik Ayak İzi Hesaplamasi. Akdeniz IIBF Dergisi, 8(15), 1-25.

Canter, M.J., \& Ndegwa, S.N. (2002). Environmental Scarcity and Conflict: A Contrary Case from Lake Victoria. Global Environmental Politics, 2(3), 40-62. https://doi.org/10.1162/152638002320310527

Cronbach, L.J. (1951). Coefficient alpha and the internal structure of tests. Psychometrika, 16(3), 297-334. https://doi.org/10.1007/BF02310555

Costanza, R. (2000). The dynamics of the ecological footprint concept. Ecological Economics, 32(3), 341-345.

Coşkun, I.Ç., \& Sarıkaya, R. (2014). Sınıf Öğretmeni Adaylarının Ekolojik Ayak İzi Farkındalık Düzeylerinin Belirlenmesi. Journal of Turkish Studies, 9(5), 1761-1787. https://doi.org/ 10.7827/TurkishStudies.6598

Dalby, S. (2008). Güvenlik ve Çevre Bağlantılarına Yeniden Bakmak. Uluslararası İlişkiler Dergisi, 5(18), 179-195.

Demirsöz, M., Özel, Z., Yonar, H., Tekin, M.E., \& Tekindal, M.A. (2021). Structural determination of the relationship between trait anxiety and personal indecisiveness for undergraduates of the faculty of veterinary medicine: The case of Selçuk University. Veteriner Hekimler Derneği Dergisi, 92(1), 6075. https://doi: 10.33188/vetheder.803804

Erkorkmaz, Ü., Etikan, İ., Demir, O., Özdamar, K., \& Sanisoğlu, S. Y. (2013). Doğrulayıcı faktör analizi ve uyum indeksleri. Turkiye Klinikleri Journal of Medical Sciences, 33(1), 210223.

Fornell, C., \& Larcker, D.F. (1981). Structural equation models with unobservable variables and measurement error: Algebra $\begin{array}{lll}\text { and } \quad \text { statistics, } & \text { 18(3), }\end{array}$ https://doi.org/10.1177/002224378101800313

Gözüm, S. (2003). A guide for transcultural adaptation of the scale II: psychometric characteristics and cross-cultural comparision. Turkish J Res Dev Nurs, 5(1), 3-14.

Güler, T. (2009). Ekoloji Temelli Bir Çevre Eğitiminin Öğretmenlerin Çevre Eğitimine Karşı Görüşlerine Etkileri. Ĕgitim ve Bilim, 34(151), 30-43

Karasar, N. (2020). Bilimsel araştırma yöntemi: Kavramlar, ilkeler, teknikler. Ankara: Nobel Yayıncılık.

Kaypak, Ş. (2013). Ekolojik ayak izinden çevre barışına bakmak. Türk Bilimsel Derlemeler Dergisi, 6(1), 154-159.

Keleş, Ö., Naim, U., \& Özsoy, S. (2008). Öğretmen adaylarının ekolojik ayak izlerinin hesaplanması ve değerlendirilmesi. Ege Eğitim Dergisi, 9(2), 1-15.

Lenzen, M., Hansson, C.B., \& Bond, S. (2007). On the bioproductivity and land-disturbance metrics of the Ecological Footprint. Ecological Economics, 61, 6-10. https://doi:10.1016/j.ecolecon.2006.10.018.
Peterson, R. (2000). A meta-analysis of variance accounted for and factor loadings in exploratory factor analysis. Marketing Letters, 11, 261-275.

Rapport, D.J. (2000). Ecological Footprints And Ecosystem Health: Complementary Approaches To A Sustainable Future. Ecological Economics, 32, 367-370. https://doi.org/10.1016/S0921-8009(99)00156-1

Ruževičius, J. (2010). Ecological Footprint As An İndicator Of Sustainable Development. Economics And Management, 15, 711-718.

Tosunoğlu, B. (2014). Sürdürülebilir Küresel Refah Göstergesi Olarak Ekolojik Ayak İzi. Hak Işs Uluslararası Emek ve Toplum Dergisi, 3(5), 132-149. 
Ecological Footprint Awareness

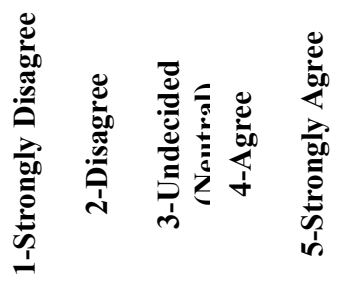

1 Clean and least environmentally damaging energy sources are my preference for heating.

I pay attention that the windows are closed when the air conditioning devices are on.

I pay attention that electrical appliances are not left on for a long time.

I prefer economical lighting and heating products.

I prefer double-glazed windows because it provides thermal insulation.

I use led bulbs instead of old bulbs at home.

7

8
I do not allow devices such as PCs, tablets and televisions to be left unnecessary.

I do not operate machines such as washing, dishwashing and drying machines before they are fully charged.

Positioning the urban structure in a way that solar energy can be used effectively is beneficial for the environment.

I think that the sale of vehicles with the least impact on the deterioration of the ecological balance should be encouraged by the government.

I think that green areas should not be abandoned for urbanization and industrialization.

I think that the measures to protect environmental health and prevent pollution of natural resources for industrial entities should be within the scope of legal obligation.

I recycle electronic waste.

I try to recycle household wastes.

I try to use leftovers in a different way instead of throwing away.

I sort the wastes in the house according to their structure and throw them away.

I prefer to use recyclable packages for shopping.

I prefer to share the same car with others as it is less harmful to the environment.

I prefer to use public transport because it is less harmful to the environment.

I prefer vehicles such as ginger, scooters and electric skateboards as they are less harmful to the environment.

$$
\text { I prefer cycling to driving. }
$$

If the distance is appropriate, I prefer walking to driving.

I do not eat foods that are not in season.

When shopping for food, I buy it as much as I need.

I cook food to the extent that it can be consumed.

When shopping for food, I prefer local products.

I prefer wiping instead of washing to ensure less water consumption in car cleaning.

I prefer cosmetic products that do not harm the environment in the content of cleaning materials.

$23-4=5$

$\begin{array}{llll}1 & 2 & 3 & 5\end{array}$

$\begin{array}{lllll}1 & 2 & 3 & 4 & 5\end{array}$

$\begin{array}{lllll}1 & 2 & 3 & 4 & 5\end{array}$

$\begin{array}{lllll}1 & 2 & 3 & 4 & 5\end{array}$

$\begin{array}{lllll}1 & 2 & 3 & 4 & 5\end{array}$

$\begin{array}{lllll}1 & 2 & 3 & 4 & 5\end{array}$

$\begin{array}{lllll}1 & 2 & 3 & 4 & 5\end{array}$

$\begin{array}{lllll}1 & 2 & 3 & 4 & 5\end{array}$

$\begin{array}{lllll}1 & 2 & 3 & 4 & 5\end{array}$

$\begin{array}{lllll}1 & 2 & 3 & 4 & 5\end{array}$

$\begin{array}{lllll}1 & 2 & 3 & 4 & 5\end{array}$

$\begin{array}{lllll}1 & 2 & 3 & 4 & 5\end{array}$

$\begin{array}{lllll}1 & 2 & 3 & 4 & 5\end{array}$

$\begin{array}{lllll}1 & 2 & 3 & 4 & 5\end{array}$

$\begin{array}{lllll}1 & 2 & 3 & 4 & 5\end{array}$

$\begin{array}{lllll}1 & 2 & 3 & 4 & 5\end{array}$

$\begin{array}{lllll}1 & 2 & 3 & 4 & 5\end{array}$

$\begin{array}{lllll}1 & 2 & 3 & 4 & 5\end{array}$

$\begin{array}{lllll}1 & 2 & 3 & 4 & 5\end{array}$

$\begin{array}{lllll}1 & 2 & 3 & 4 & 5\end{array}$

$\begin{array}{lllll}1 & 2 & 3 & 4 & 5\end{array}$

$\begin{array}{lllll}1 & 2 & 3 & 4 & 5\end{array}$

$\begin{array}{lllll}1 & 2 & 3 & 4 & 5\end{array}$

$\begin{array}{lllll}1 & 2 & 3 & 4 & 5\end{array}$

$\begin{array}{lllll}1 & 2 & 3 & 4 & 5\end{array}$

$\begin{array}{lllll}1 & 2 & 3 & 4 & 5\end{array}$

$\begin{array}{lllll}1 & 2 & 3 & 4 & 5\end{array}$ 


\begin{tabular}{|c|c|c|c|c|c|c|}
\hline 29 & I take care not to waste more water than necessary for personal cleaning. & 1 & 2 & 3 & 4 & 5 \\
\hline
\end{tabular}

Ekolojik Ayak İzi Farkındalık Ölçeği

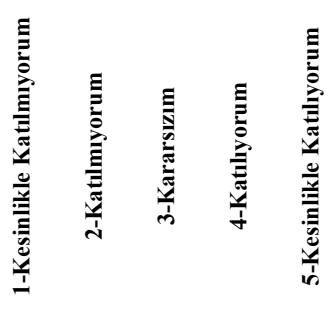

\begin{tabular}{|c|c|}
\hline 1 & Temiz ve çevreye en az zarar veren enerji kaynakları 1sınmada tercihimdir. \\
\hline 2 & İklimlendirme cihazları açıkken pencerelerin kapalı olmasına dikkat ederim. \\
\hline 3 & Elektrikli ev aletlerinin uzun süre açık kalmamasına dikkat ederim. \\
\hline 4 & Tasarruflu aydınlatma ve ısıtma ürünlerini tercih ederim. \\
\hline 5 & Pencerelerin çift camlı olmasının ısı yalıtımı sağladığı için tercih ederim. \\
\hline 6 & Evde eski ampuller yerine led ampuller kullanırım. \\
\hline 7 & PC, tablet ve televizyon gibi cihazların gereksiz açık kalmasına izin vermem. \\
\hline 8 & Çamaşır, bulaşık, kurutma...gibi makineleri tam doldurmadan çalıştırmam. \\
\hline
\end{tabular}

9 Kentsel yapılanmada güneş enerjisinin etkili kullanılabilecek konumlandırılması çevre için faydalıdır.

Araçların, ekolojik dengenin bozulmasına etkisi en az olan araçların satışının devlet tarafından teşvik edilmesi gerektiğini düşünürüm.

Yeşil alanlardan şehirleşme ve sanayileşme amacıyla vazgeçilmemesi gerektiğini düşünürüm.

Endüstri kuruluşları çevre sağlığını koruyacak ve doğal kaynakların kirletilmesini önleyecek tedbirlerin yasal zorunluluk kapsamında olması gerektiğini düşünürüm.

Elektronik atıkları geri dönüşüme kazandırırım.

Evsel atıkların geri dönüşüme kazandırmaya çalışırım.

Evdeki atıkları yapılarına göre ayrıştırarak çöpe atarım.

Alışverişte geri dönüşüme uygun paketleri kullanmayı tercih ederim.

Aynı arabayı başkalarıyla ortaklaşa kullanmayı çevreye daha az zarar verdiğinden tercih ederim.

Toplu taşıma araçlarını kullanmayı çevreye daha az zarar verdiğinden tercih ederim.

Ginger, scooter, elektrikli kaykay gibi araçları çevreye daha az zarar verdiğinden tercih ederim.

Bisiklet sürmeyi, araç kullanmaya tercih ederim.

Mesafe uygunsa yürümeyi ,araç kullanmaya tercih ederim.

Mevsiminde olmayan yiyecekler yemem.

Gıda alırken ihtiyacım kadar satın alırım.

$\begin{array}{lllll}1 & 2 & 3 & 4 & 5 \\ 1 & 2 & 3 & 4 & 5 \\ 1 & 2 & 3 & 4 & 5 \\ 1 & 2 & 3 & 4 & 5 \\ 1 & 2 & 3 & 4 & 5 \\ 1 & 2 & 3 & 4 & 5 \\ 1 & 2 & 3 & 4 & 5 \\ 1 & 2 & 3 & 4 & 5\end{array}$




\begin{tabular}{lcccccc}
\hline 25 & Tüketilebilecek kadar yemek pişiririm. & 1 & 2 & 3 & 4 & 5 \\
26 & Gıda alışverişi yaparken yerli ürünleri tercih ederim. & 1 & 2 & 3 & 4 & 5 \\
27 & Araba temizliğinde daha az su tüketimini sağlamak için yıkama yerine silme işlemini tercih ederim. & 1 & 2 & 3 & 4 & 5 \\
28 & Temizlik malzemelerinin içeriğinde çevreye zarar vermeyen kozmetik ürünleri tercih ederim. & 1 & 2 & 3 & 4 & 5 \\
29 & Kişisel temizlik için gereğinden fazla su israfi yapmamaya özen gösteririm. & 1 & 2 & 3 & 4 & 5 \\
30 & Evdeki/bahçedeki bitkileri doğru yöntemleri kullanarak sulamayı tercih ederim. & 1 & 2 & 3 & 4 & 5 \\
\hline
\end{tabular}

\section{Annex II}

The study the Awareness Scale for Reducing the Ecological Footprint consists of six sub-dimensions: Energy, Under the Laws, Recycling, Transportation, Water Consumption and Food. Energy sub-dimension 1., 2., 3., 4., 5., 6., 7., 8. Under Laws, 9., 10., 11., 12., Recycling 13., 14., 15., 16., 17., Transportation 18., 19., 20., 21., 22., Food 23., 24., 25., 26., Water Consumption 27., 28., 29., 30. It consists of questions. Scale categories; It is obtained by summing the subscales by scoring Strongly Disagree $=1$, Disagree $=2$, Undecided $=3$, Agree $=4$ and Strongly Agree $=5$.

Çalışmada Ekolojik Ayak İzinin Azaltılmasına Yönelik Farkındalık Ölçeği Enerji, Yasalar Kapsamında, Geri Dönüşüm, Ulaşım, Su Tüketimi ve Gıda olmak üzere altı alt boyuttan oluşmaktadır. Enerji alt boyutu 1., 2., 3., 4., 5., 6., 7., 8., Yasalar Kapsamında 9., 10., 11., 12., Geri Dönüşüm 13., 14., 15., 16., 17., Ulaşım 18., 19., 20., 21., 22., Gıda 23., 24., 25., 26., Su Tüketimi 27., 28., 29., 30. sorulardan oluşmaktadır. Ölçek kategorileri; Kesinlikle Katılmıorum=1, Katılmıyorum=2, Kararsızım=3, Katıliyorum $=4$ ve Kesinlikle Katıliyorum $=5$ şeklinde puanlanarak alt ölçeklerin toplanması ile elde edilmektedir. 